\title{
ENERGY SECURITY AND THE PROBLEM OF PERIPHERALITY: CASE STUDY OF THE CEE REGION BETWEEN RUSSIA AND THE EU
}

\begin{abstract}
The article presents the issues of energy security with regard to centerperipherality theory using Central and Eastern Europe as an example. Until now the subject of energy security has not been discussed in the context of this theory and the author presents the question of peripherality of the region in terms of energy policy. Due to their long-lasting historical, political and economic dependence, CEE states do not possess secure and well-diversified sources of energy supply; in this area they depend on Russia. Moreover, they do not have an appropriate level of technology for investing in the latest and most ecological energy resources typical for the wealthy states of the former EU-15. Thus, their capability to influence the agenda of EU energy policy is lower than those of the EU-15 states. The following article aims to define the factors of peripherality and to examine its influence on the energy security policy adopted by CEE states.
\end{abstract}

\section{Key words}

periphery, peripherality, energy security, security policy 


\section{Introduction}

The article aims to present the issue of energy security with regard to the centerperiphery model. This approach is taken in order to describe and explain one dimension of the dependence of the Central-Eastern Europe region (CEE) on dominant neighboring states. The theoretical framework which was the inspiration for this approach originates in regional security complex theory and the theory of security sectors, formulated by Barry Buzan (Buzan, 1993; Buzan $\&$ Hansen, 2009). According to these, the majority of security threats to a state result from its immediate surroundings, i.e. the political region. Buzan distinguished political, military, economic, social and ecological sectors of security. This list does not include a separate energy sector dimension and its related technological aspects, which are crucial from the point of view of various theories of modernization. The issue of energy security appeared later in the academic debate as a typical issue since it cuts across all other sectors dimensions.

Juxtaposing the issue of energy security with the center-periphery model allows the process of devising energy security policy, in the context of attempts made by states to achieve a higher international status, to be shown. States which enjoy relative energy independence and which possess technology in the energy area are able to ensure an effective functioning of social and economic order. Meanwhile, those states which are relatively dependent in terms of energy find themselves simultaneously in a subordinate position in numerous aspects. A broader discussion in the European Union was initiated only at the turn of the century, triggered by the unpredictable policy of the Russian Federation towards several states of Central and Eastern Europe.

The article consists of several parts. Firstly, it the presents theoretical framework for the discussion explaining the concept of peripherality and the way in which it can be applied in an analysis of security policy. Next, it analyzes energy policy in the CEE region and examines how the states there try to 1) overcome their energy dependence on Russia, and 2) neutralize the economic and technological dominance of the states in Western Europe. From the center-periphery point of view, among numerous monographs devoted to the CEE region the one that provided most inspiration was a publication by Tomasz Zarycki on understanding the idea of "eastness" in the CEE region (Zarycki, 2014). 
The desired result is to verify whether theories of center-periphery are suitable for analyzing security policy and to partially explain the issue of the dependence of the CEE region on outside states. The article is a theoretical analysis combined with a case study, situated in the social science research tradition. Analysis of CEE energy security issues as an interdisciplinary problem is an attempt to enrich security theory with new patterns of interpreting social phenomena.

\section{What is peripherality?}

In this part of the article the center-periphery theory in its relation to the issue of energy security will be defined. The word "periphery" is of Greek origin and signifies "circumference" or "outer surface". The word "peripheral" was recorded in English around the year 1808. A semantically related word "marginal" was recorded in 1887; it is derived from the term "margo" (boundary, edge). In both cases, what is described by these words matters less (Danson \& De Souza, 2012, pp. 3-10). Peripherality is defined negatively in relation to the core/center as something opposite to what attracts attention, something subordinated to something dominant. Peripherality means "otherness", a remainder of something, remoteness from somewhere. Being "other" or being a remainder reveals a good deal about relations between place, people and power. Peripherality is usually defined as something negative: it refers to what is deprived of the benefits of the center. Peripherality is sometimes also defined as being unable to influence the processes and structures of power. According to the center-periphery models used in the social sciences, the world comprises dominant and subordinate regions, i.e. centers and peripheries. Both types have differing material and non-material resources, and peripheral regions are usually dependent on central ones.

At the beginning of the second half of the $20^{\text {th }}$ century, South-American researchers started to develop the center-periphery model. Raul Prebisch (1959) aimed to prove that centuries of European colonialism had made entire continents dependent on the European economic model. $19^{\text {th }}$-century Europe was the political and economic center of the world, imposing its military and economic practices on whole civilisations in Africa, Asia and America. The Europeans made it impossible for the conquered peripheral countries to modernize and saw them as markets for European goods and technologies. The peripheries could export only raw materials and unmanufactured goods which brought little profit, while manufactured goods were brought from the metropolises and 
sold at significantly larger profit. Transport and energy flow were controlled by the center. According to Raul Prebisch (1959), several centuries of implementing such a model of capitalism destroyed the political and economic independence of numerous states.

Mechanisms defined by Prebisch were translated at an international level by Immanuel Wallerstein (1974) who incorporated the center-periphery model into the logic of functioning of Western capitalism. The two model types of economy - center and periphery - provided goods for each other following the pattern defined by Prebisch. Wallerstein complemented the center-periphery dyad with a category of semi-periphery, areas also dependent on centers but enjoying certain degree of political independence. Thus, the main point of reference developed in Wallerstein's socio-economic model was a world-economy with a global reach, whose origins date back to the $16^{\text {th }}$ century (Wallerstein, 2001, pp. 10-20). Wallerstein's perspective gained significant popularity as well as supporters among geographers, sociologists and political scientists; his works are published in many languages (Babones \& Chase-Dunn, 2012; El-Ojeili, 2014). Importantly, centers, semi-peripheries and peripheries are hierarchically connected regions of specific economic potential. A regional center (e.g. located in Germany) develops economic and political models, semi-peripheries (e.g. Czech territory or western Polish lands) attempt to conform to these models, while the peripheries (e.g. Ukrainian territory) are economically dominated by centers and semi-peripheries located in neighboring countries with stronger economies. Peripherality can refer not only to states but also to whole macroregions such as Central and Eastern Europe (CEE), which is dominated by Russia in terms of energy and by the states of the former EU-15 with regard to policy and economy. CEE countries still have limited possibilities to influence the rules of international politics and economy. The European Union as a separate structure is able to relatively limit the dominant EU countries and provide all its member states with equal development opportunities through inter-governmental and international mechanisms.

The author of the second center-periphery model was a Norwegian political scientist Stein Rokkan. His model was developed in 1977-79 under the patronage of the European Consortium of Political Research. In the volume of collected studies Center and Periphery: Spatial Variation in Politics, Rokkan's text is an attempt to construct a model explaining the ethnic, economic and political diversity in Europe from a geographical perspective (Rokkan, 1980, pp. 37-57). In 1982 Rokkan together with Derek Urwin edited a further volume of collected studies, The Politics of Territorial Identity: Studies in European Regionalism 
(Rokkan \& Urwin, 1982). Here it was noted that the increased internationalisation of transactions on a global scale leads to a decrease in resources remaining under the political control of the regions. As a result, local societies are increasingly disturbed. The authors distinguish two types of background for conflicts between centers and peripheries. The first is cultural differences (language, religion, ethnicity of the center and the peripheries); the other is economic differences between the centers controlling resources and trade. At this point, the difference between the concepts of center and periphery is introduced. Centers can be defined as privileged territories which own key resources and military, administrative, economic and cultural institutions. Modern political-economic centers have a developed "deliberative" sphere and complex decision-making processes; thus they are communication nodes. To summarize, the centers maintain control over resources and communication in three spheres: 1) political control, 2) economic dominance and 3) cultural standardisation; they fulfil their role by controlling key transactions in a given territory.

In contrast to centers, peripheries are dependent; they control only their local resources and have little influence over processes occurring elsewhere. Rokkan \& Urwin (1982) highlighted two patterns of territorial structures present in modern-day states: a monocephalic model (territorial structures dependent on a single center, e.g. the capital or a neighboring power) and a polycephalic model (territorial structures dependent on several centers) (pp. 4-12). The CEE region represents the second model. States in this region to a large extent remain dependent on Russia with regard to energy, but their political and economic success depends on their position within the European Union.

What follows the division defined by Rokkan are different political and economic strategies concerning standardisation, centralisation and unification, often concordant with the interests and interpretation of the dominant region, i.e. the center. The issue of peripherality delineated above in the Rokkan-Urwin model was developed in their next work Economy, Territory, Identity: Politics of West European Peripheries, published in 1983 after Rokkan's death (Rokkan \& Urwin, 1983). Based on the research material collected and encompassing several centuries of European history, the authors drew a conclusion concerning the features of the regions' peripherality. Such regions do not control their fate, are poorly represented in politics, often comprise a territory that is foreign and/ or conquered, often poorly developed economically, geographically distant, with less developed infrastructure, diversity of cultural models and communication. This model includes three fundamental areas of interaction: political, economic and cultural (Rokkan \& Urwin, 1983, pp. 3-5). Thus, the authors formulated 
a "three-dimensional" (3D - distance, difference, dependence) characteristic of peripheries as presented in the table below.

Table 1. Periphery characteristics according to Rokkan \& Urwin

\begin{tabular}{|l|l|}
\hline Feature of peripheries & Description \\
\hline Distance & Peripheries are distant from the center \\
\hline Difference & Peripheries differ from center models in several spheres \\
\hline Dependence & Peripheries are dependent on one or several centers \\
\hline
\end{tabular}

Source: based on Rokkan \& Urwin, 1983, pp. 3-4.

A variety of transactions take place in the spheres of politics, economies and culture. As has been said, centers control the majority of transactions as they control most of the information transfer in a given system: they make their own messages universal, and build hierarchies of values and fashions in desirable goods and resources. Resource exchange is present in several dimensions and is not only dominated by economic interactions as Immanuel Wallerstein's school teaches. The center's aim is to dominate the peripheries by including them in the center's own political, economic and cultural circulation of ideas and social practices. In this understanding, the center is active, it imposes models, establishes institutions, promotes standardisation and distributes resources such as energy and technology. Peripheries remain reactive and unable to defend themselves against the expansion of the stronger party. Centers use a variety of resources to dominate less developed regions and give them the status of subordinate areas. This scheme matches most historical state structures of an imperial nature.

A fundamental process in each sphere of center-periphery relations is penetration of the periphery's territory by the center's resources as similarly described by the sociologist Pierre Bourdieu (1986). The expansion of a center's models and resources into peripheral regions is noticeable in several ways, such as the appearance of foreigners (colonists, officials, troops), foreign ideas (literature, system of education, language and intellectuals), and foreign products (raw materials, money, goods, services offered by specialists from the metropolises). The center's intervention in the periphery results in an administrative, cultural and economic system dependent on the center and managed by specialists who have come from the center. Peripheral cultural codes, institutions and practices 
are considered "worse" because they are "merely local", "particular" and "limited". What becomes a necessary condition for promotion, career advancement or opening a business is knowledge of the new codes (skills, behaviour) connected with the center, which are thought to be "better" as they are "universal", "profitable", "fuller", "more popular" and "more genuine".

Table 2. Comparison of the resources of centers' domination over peripheries according to Rokkan and Bourdieu

\begin{tabular}{|l|l|l|l|}
\hline Processes & Process in culture & Process in economy & Process in politics \\
\hline $\begin{array}{l}\text { Terminology: } \\
\text { Rokkan }\end{array}$ & Cultural standardisation & Economic domination & Political control \\
\hline Resources & Resources in culture & Resources in economy & Socio-political resources \\
\hline $\begin{array}{l}\text { Terminology: } \\
\text { Bourdieu }\end{array}$ & Cultural capital & Economic capital & Social capital \\
\hline
\end{tabular}

Source: author's own research.

An attempt to combine Bourdieu's and Rokkan's approaches leads to the conclusion that peripheral regions are dominated in three macro-areas: economy, culture and politics. Centers control resources (cultural, economic and sociopolitical), and control the sphere of communication (symbolic capital) which gives meaning to individual resources. Peripheries do not have equal resources and must adapt, accepting diminished security in exchange for survival and access to desirable resources.

It is worth emphasising that center-periphery models are not precise: they do not define specific parameters of social change (as these are different in particular regions or periods) and lack a direct reference to energy. We can assume that it is a "preliminary resource": it enables the development of technologies and economy that lets some economic centers dominate peripheries. Therefore ensuring energy security seems to be a key process. In contemporary research this process is connected with a broader category of economic security meaning the uninterrupted functioning of economies, i.e. maintaining basic development indices and ensuring a comparative balance with other states' economies (Księżopolski 2011, p. 24). The academic discourse differentiates four sectors of economic security: finance; raw materials and energy; food; access to unpolluted water. Thus, understood energy security is a focus of policy. In the contemporary 
world state security policy comprises matters of both internal and external security, related to securing the needs and interest of the people represented by a given state. Security policy is the purposeful activity of a state institution whose task is to build, maintain and develop military and non-military systems of national security in case of local or international challenges or threats. The main elements influencing energy security include 1) diversification of raw material supply, 2) strategic reserves, 3) diverse and multiple systems of key energy infrastructure, 4) flexibility of raw material markets, 5) interdependence between suppliers and consumers of raw materials, and 6) investments in technology (Yergin, 2005).

\section{Energy and peripherality}

The development of a modern economy depends on energy supply while innovations in energy production have resulted in a complete transformation of the world order. The technological revolution led to the energy revolution and the industrial revolution, which in turn changed the balance of power in the world. What emerged was the center-periphery system, in which old civilisations on other continents became colonialized and peripheralized due to the dominance of the West (Buzan, 2016, pp. 2-10). As a result of the development of steam engine technology, followed by modern steelmaking processes as well as the appearance of internal combustion engines, the chemical industry and electricity, industrialized Western states achieved dominance over the rest of the world in practically all spheres (Klementewicz, 2013, p. 266). For almost the entire $20^{\text {th }}$ century, the degree of modernisation of a given country was measured by its industrialisation index and its ability to produce and manage use energy. Education and innovativeness still remain key factors in the development of societies and states (Wojciuk, 2018). The origins of asymmetry in the potential of states over the last two centuries can be explained by analysis of their energy resources, energy per capita and the energy use of their economies, which is a measure of their technological advancement.

This can be exemplified by Figure 1, prepared by Gapminder, an academic think tank providing information on economic inequality in the world. The graph shows that energy supply per capita in the most developed economies (member states of the OECD) is more than twice as high as that of the rest of the world, despite the fact that the former often do not have their own energy resources. 
Figure 1. Differences in energy supply in OECD and non-OECD countries

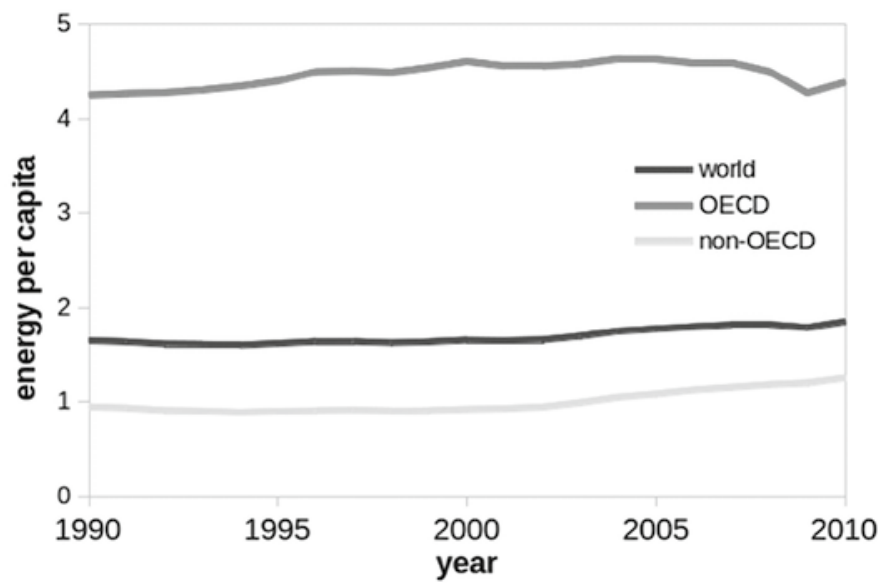

Source: https://www.gapminder.org/

EU member states account for ca. $11.5 \%$ of world energy consumption, yet only $5.6 \%$ of world energy production. At the beginning of the 2010 s, only four EU members had oil resources (Denmark, Italy, Romania and the United Kingdom), and seven had gas resources (Denmark, Germany, Italy, the Netherlands, Poland, Romania and the United Kingdom) (BP Statistical Review of World Energy, 2010). The European Union imports $88 \%$ of oil, $67 \%$ of gas and overall $45 \%$ of all its fuel. Approximately a third of the imported coal, oil and gas comes from Russia (EU Energy in Figures, 2016). At first glance, these statistics could suggest that the EU is an economically peripheral region as it does not own energy supplies and has to import them. However, in contemporary economies the extraction of traditional raw materials and the petrochemical industry are perceived as "lower" technologies, and their dominance in the economic profiles of states is characteristic of semi-peripheral or peripheral states (OECD Science, 2005). In the $19^{\text {th }}$ and $20^{\text {th }}$ centuries central states built efficient systems of energy processing, and developed highly efficient, energy-saving technologies, so that they were able to maintain high levels of energy supply and obtain energy resources from less developed states, and even, with a repertoire of different tools, to impose their own political agenda. With high technologies, rich EU states can invest in renewable energy sources so that they are not threatened by potential disputes with energy suppliers. As Beata Molo (2016) noted, in the EU the share of renewable resources in primary energy production increased from 
$10.3 \%$ in 2000 to $24.3 \%$ in 2013 . Between 1990 and 2013 production from renewable sources increased by $170 \%$. In the $21^{\text {st }}$ century, the growth rate of energy production from renewable sources was the greatest among all energy sources in the $\mathrm{EU}$ (p. 122).

According to the theory of Pierre Bourdieu, states are able to invest the resources they have and obtain new ones in other areas. Bourdieu distinguished cultural, economic and social resources. For example, a state with considerable cultural resources (e.g. monuments) can develop tourism; thus, cultural capital leads to the development of economic capital. In another case, economic resources (e.g. natural resources or expansive businesses) may lead to investments in education (social capital) and works of art (cultural capital). In Bourdieu's concept, a separate form of capital is symbolic capital creating senmantic fields fields of meaning, which assign importance to specific forms of capital. The purpose of all forms of capital is to reproduce and develop their resources.

Figure 2. Relations between energy supply and social development

\section{Social Progress Index vs Energy per country}

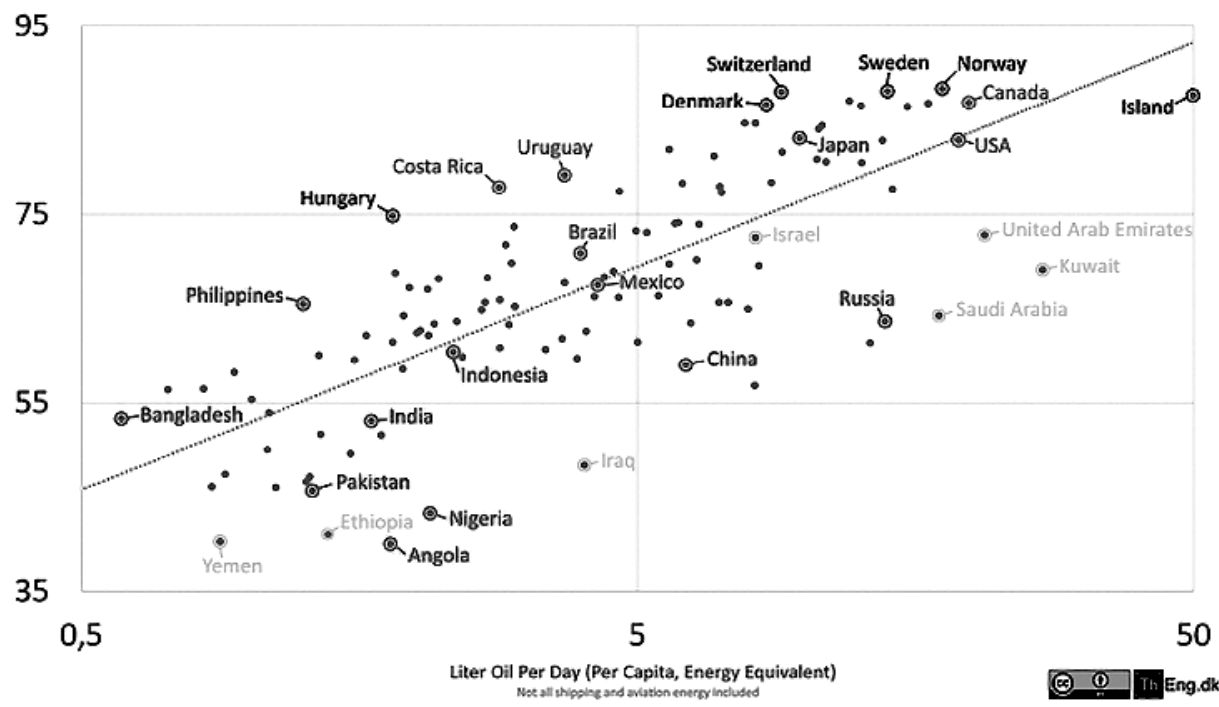

Source: Wikimedia Commons, https://commons.wikimedia.org/wiki/File:SpcialProgressIndex VsEnergInOilPerDay2.png 
The graph above points to the relations between the level of socio-economic development, energy supply and energy efficiency. States rich in different forms of capital are able to obtain considerable energy resources, use them efficiently and support the social development of their populations. Thus, the majority of the oil-rich countries of the Middle East and states such as Russia and China, which possess considerable energy resources, still are unable to compete with Western states in terms of energy efficiency and innovations facilitating technological development. Here the highest rates are achieved by European and North-American countries; due to the limited size of their own resources, they focus on energy diversification and the development of renewable energy sources. The 2010 forecasts predicted a significant increase in EU dependency on Russian gas, which was to be an effect of an energy import increase, estimated to be $c a .70 \%$ by 2030 (Olszewski, 2010). However, energy has not always been the main focus of European decision-makers.

The origins of the contemporary energy policy of European states date back to the mid-20th century. The Treaty establishing the European Coal and Steel Community was signed in 1951; the European Atomic Energy Community and the European Economic Community were established in 1957. At that time, energy supply was not considered as a key state security issue. Using constructivist language: energy matters were not subjected to the process of securitisation. Western countries dominated the world economically while coal and oil, on which the energy industry was based, were cheap and available. The main reason for the growing interest in energy security was the 1970s oil crisis when OPEC member states decided to impose sanctions on Western countries that supported Israel in the Yom Kippur War. The OPEC states caused a rise in the price of fuels by limiting extraction and decreasing exports, and the result was a rise in oil prices from less than 3 USD per barrel to $c a$. 11 USD (Golarz, 2016, p. 162).

The first European regulations were implemented by the mid-1970s and concerned stockpiling fuels against a possible supply disruption. In the following years, EEC member states lost interest in developing further regulations as world fuel prices remained stable. Only in 1988 did the member states decide that the energy industry could be aligned to the rules of the common European market. At the turn of the millennium, the industrialisation of Asian states, the instability of the former USSR region and the growing number of conflicts in the oil-rich Middle East region raised concerns as to energy security in Europe.

The first act of primary legislation partially devoted to energy security was the 1992 Treaty on European Union (called the Maastricht Treaty). Article 3 of the Treaty included energy as one of the spheres in which the Community 
should take measures, and Article 129b stated that "the Community shall contribute to the establishment and development of trans-European networks in the areas of transport, telecommunications and energy infrastructures". The fact that the EU was now able to decide on a route to co-finance trans-European networks of energy infrastructure was an important step, but was a mere standin for a comprehensive policy. The subsequent Treaties, of Amsterdam (1997) and Nice (2000), did not contain provisions for a common energy policy either.

A significant change in the status of the energy question was made in 2004 in the Treaty establishing a Constitution for Europe; however, that treaty was not ratified. All the proposals pertaining to energy were included in the Treaty of Lisbon, which entered into force on 1 December 2009, thus setting for the first time the main objectives of the EU's common energy policy and a basis for adopting regulations in the sphere of energy. Title XXI of the Treaty of Lisbon contains provisions regarding such institutions as a liberalized common market, security of supply, environmental protection, the development of alternative energy forms and promotion of the interconnection of energy networks (Krzak, 2010). Notably, in the Treaty of Lisbon the member states still maintain a strong position in developing their own energy policies. Each member state can freely shape its energy balance preferring specific energy sources as well as forms and directions of supplies. The 2000s saw the introduction of regulations within the so-called second and third energy packages, which laid the foundation for the EU's energy policy. Furthermore, a financial instrument named Connecting Europe Facility was introduced to finance energy projects in the member states (such as thousands of kilometers of gas pipelines in Central European states).

In European documents, declarations and reports of the 2010s, energy security has become a keyword in maintaining cohesion and the planning of EU development. On 5 May 2010 the President of the European Parliament, Jerzy Buzek, and the former President of the European Commission, Jacques Delors, presented the Declaration Towards A New European Energy Community and proposed establishing an eponymous institution (Delors \& Buzek, 2010). In 2011 the Commission issued a communication Energy Roadmap 2050, presenting the long-term strategy and direction of EU activity in the sphere of energy, and mentions that the EU will be substituting coal and oil with gas as it is far less polluting (Energy Roadmap 2050, 2011). This would allow the European Union to achieve its goals regarding climate change. In 2014 the European Commission published a communication European Energy Security Strategy, which contained short-term as well as medium- and long-term goals in the gas sector (European Energy Security Strategy, 2014). In July 2014 the new President of the European 
Commission, Jean-Claude Juncker, announced in his inauguration speech the intention of transforming European energy policy into a European Energy Union (Juncker, A New Start for Europe, 2014).

On 25 February 2015 the Commission published the Energy Union package, consisting of three communications on 1) a framework strategy for energy union, 2) new global climate agreement, and 3) the project of achieving a target of $10 \%$ electricity interconnection by 2020 . The strategy proposed that the European Commission should be informed about negotiations of gas purchased between a member state and a third state before the conclusion of the agreement. EU states which import gas mostly from a single supplier are at a disadvantage in negotiations, so the supervision of the European Commission increases the possibility of negotiating better conditions for a member state. The establishment of the Energy Union is planned for the spring of 2019 (Energy Union for Europe, 2018).

The center-periphery perspective can thus be applied to briefly summarize EU activity aimed at ensuring its energy security. In the decades after the end of the Cold War, EU states built a common legal and decision-making system facilitating easier supply of energy from peripheral states. This gave the EU a more favourable position in negotiations and the possibility of implementing a diversification policy, which is essential for energy security when there are several sources of energy and forms of supply. Thus EU states maintain all three attributes of centrality:

- economic benefits (minimized risk of losing energy security),

- dominant status (in relation to energy suppliers),

- development of attractive cooperative culture (law, treaties, consultation mechanisms) which forms a model for peripheral states.

Furthermore, the matter of energy security has been rhetorically connected with environmental protection norms as well as ideas of sustainable development and human rights, thus producing another field of symbolic dominance for European states in international relations. The changes delineated above were of particular importance for the CEE states which joined the EU in the first decade of the $21^{\text {st }}$ century. 


\section{Energy Security in Central and Eastern Europe}

The region of Central and Eastern Europe is the historical area situated between the territories where the dominant languages are German or Russian. This region flourished in the $16^{\text {th }}$ century, and then it succumbed to its stronger neighbors. In the modern period, it has become an agricultural and peripheral area. Legal, commercial and industrial institutions sometimes appeared there after several centuries' delay. In the $19^{\text {th }}$ century, the multi-national Austrian, Russian, Turkish and German empires, dominant on this territory, were still less wealthy than Western European countries which were growing rich thanks to overseas trade. Income in CEE countries was consumed mainly by landowners, which inhibited the development of industry, trade, investment, modern energy and the implementation of new technologies. As a result, just before World War I, Polish lands, representative of this region, generated per capita only $24 \%$ of European average production, and in 1936-38 only $20 \%$. During the same periods Romania was at $10 \%$ and $16 \%$ respectively, Hungary $35 \%$ and $43 \%$, Czechoslovakia $50 \%$ and $67 \%$. This region was peripheral to Western Europe and, due to half of its population being employed in agriculture, was considered in the first half of the $20^{\text {th }}$ century as a backward region (Pawłuszko, 2017).

The period of communism facilitated not only significant development in the material infrastructure in the CEE region (roads, railways, schools, hospitals) but also the building of a regional energy system based on the USSR's dominance. As peripheries, the states of the region used the USSR's energy resources and, by acting in the interests of the central office, enabled Moscow to export its raw materials to the west of Europe. After the fall of the Eastern Bloc, the region of Central and Eastern Europe, once the periphery of the USSR, became the periphery of integrated Western Europe. Twenty years after the fall of the Eastern Bloc, the twenty countries of Central and Eastern Europe (from Estonia to Bulgaria), whose population was 190 million people, $25 \%$ of the total population of Europe, produced only $10 \%$ of the continent's GDP. The aim of the authorities in Poland and other peripheral countries of the Eastern Bloc was to make their institutions similar to "model" Western European ones and "catch up" with the average level of wealth of the countries forming the former EU-15 (Orłowski 2010, pp. 11-12). The accession of CEE states to NATO and the EU was treated as a historic civilizational challenge and the moment of "using the opportunity" to join one of the centers of the world economy. 
After the fall of the Eastern Bloc, the level of development of individual regions ranged from about 35\% of the European average in Romania to around $70 \%$ in Czechoslovakia. In the first decade after accession to the EU, the EU-10 countries thanks to the convergence process, leveled out their wealth in relation to the EU-15. For instance, in 2004-12, cumulative growth in GDP in Poland amounted to $46.3 \%$, while in the EU it increased by $10.8 \%$ in total (Kostecki, 2016, p. 60). That fact translated into reducing the distance between Poland and the average level achieved in the EU. The report issued by the Ministry of Foreign Affairs to summarize the tenth anniversary of Poland's EU membership showed that in 2004 the ratio of gross domestic product per capita (expressed as the purchasing power standard, PPS) to the EU average was 51\%, and among 28 countries Poland was $25^{\text {th }}$. In 2012, this rate increased to $67 \%$ of the average for the EU, which put Poland in $23^{\text {rd }}$ place, ahead of Bulgaria, Romania, Croatia, Latvia and Hungary (Departamet Ekonomiczny UE, 2014). Despite the leveling of living standards in Europe, the CEE region remained largely dependent on the energy networks of the former center of the Eastern Bloc and was subject to the penetration of standards and investments coming from the Western European center.

Energy markets in the CEE region differ significantly. Poland and Ukraine consume separately more energy than the Czech Republic, Hungary and Slovakia together. Poland and the Czech Republic rely heavily on coal. In Hungary, nuclear energy is a significant share of domestic production. Estonia and Romania have their own small oil, gas and coal deposits, and Latvia uses a significant level (37\%) of renewable sources. As the authors of the Central Europe Energy Partners report note, all countries in the region have experienced stagnation in energy consumption. The largest decrease (over 30\% in the period 2010-15) concerned Ukraine. Estonia and Romania are independent to a high degree (they imported respectively $9 \%$ and $17 \%$ of energy in 2014). In the mid-2010s, Poland and the Czech Republic produced about one third of energy resources needed, and imported the rest. Slovakia and Hungary imported over $60 \%$ of resources, and Lithuania almost 80\% (Energy security quest, 2016).

European economies are growing, thus EU energy imports and production are increasing. Many EU countries have managed to ensure efficient diversification of energy supply and production. The significance of renewable energy sources is increasing, planned in several decades to result in energy self-sufficiency in the EU. Meanwhile, energy consumption is declining in small CEE countries and in Ukraine and they are trying to obtain energy resources through the EU. Ukraine follows this path too as it liberalized the market and in 2015 its import 
of gas from the EU exceeded significantly imports from Russia (this is also the effect of Ukraine losing a part of its industrialized territory). However, Russia remains a leading player in the region for geographical and historical reasons. CEE energy infrastructure is still oriented towards the transport of resources on an East-West axis. Key gas pipelines run through CEE, supplying EU countries with gas, coal and oil; they include the Druzhba (Russia-Ukraine-Slovakiathe Czech Republic with a branch from Ukraine to Hungary), the Yamal-Europe (Russia-Belarus-Poland-Germany) and the Trans-Balkan gas pipeline (RussiaUkraine-Moldova-Romania-Bulgaria). In total, as much as $66 \%$ of deliveries from Russia to Europe run through Ukraine (Paszkiewicz, 2018). The fourth connection is the Nord Stream Baltic gas pipeline, currently being developed since Russia also wants to reduce its dependence on Ukrainian transit.

Due to long-term Soviet dominance, CEE countries still do not have sufficiently developed gas markets. However, they are trying to become independent from Russia by expanding interconnectors (Hungary, the Czech Republic, Romania, Slovakia) and coastal LNG gas terminals (Lithuania and Poland). The Balkan countries are much less diversified. All countries in the region, even non-EU members, are trying to adopt EU standards (the Third Energy Package) with regard to the gas market model and - more recently - in the implementation of renewable energy sources. Interestingly, some countries in the region (Romania, the Czech Republic, Poland, Slovenia and Bulgaria) have increased electricity production. In Poland and the Czech Republic, coal plays a significant role in energy production (around $80 \%$ and almost $50 \%$ respectively), and nuclear energy is important in Hungary, Slovakia and the Czech Republic (responsible for approximately 55\%, 50\% and 35\% of energy production respectively). In Ukraine in 2015 , nuclear power was responsible for around $56 \%$ of electricity production.

CEE countries are in the process of catching up with the EU-15 and it is assumed that energy consumption will be growing. Even today, Visegrad Group countries meet EU requirements in the area of cross-border energy connections declared in the strategy from 2015. The situation is worse in Ukraine and the Baltic states, which as post-Soviet territories still have their energy systems technologically connected with Russia. It should be mentioned that the condition of the infrastructure present in CEE is worse than in the EU-15 countries. Power equipment is old, energy efficiency lower, and transmission losses are several percent higher.

In the mid-2010s, CEE countries imported a large part of the energy consumed in their territory. In the case of Poland and the Czech Republic, it was almost $30 \%$, in the case of Slovakia and Hungary around $60 \%$, while the EU 
average was 53.5\%. Thanks to their own resources and the development of energy connections with the EU-15 countries, the leading CEE countries are slowly gaining opportunities for energy diversification. Owing to numerous investments, energy companies have become the largest companies in the region. A huge difference between CEE and the EU-15 is still caused by the lower level of technological infrastructure in CEE and its less diversified energy mix. In the EU-11 (i.e. the member states which joined the EU in 2004 and 2007 plus Croatia), $64 \%$ of energy still comes from fossil fuels, while in the EU-15 it is only $43 \%$, and this figure is constantly decreasing in favour of renewable resource energy. The countries of the European core are increasingly affecting the EU agenda, and appeal to CEE states to comply with the standards of low-carbon economies (Energy security quest, 2016).

Summing up the above outline, CEE countries have quickly adopted EU legislation (and even partially influenced its shape) as well as decreased their own energy dependence on Russia, but they still have deficiencies in energy infrastructure and a lower energy efficiency than EU-15 countries. Their energy resource makeup is not on a par with the diversified and greener trend in the EU-15 either. However, the integration of the CEE region into the European Union is so advanced that international statistics take Europe as a whole without dividing it into western and eastern regions, etc. (BP Energy Outlook, 2018). It seems that this is the effect of adjusting CEE to EU standards and establishing the foundations of European energy market. The political, economic and cultural drive of these changes was the development of the center of the European system.

The development of energy policy in the EU was modelled on the successes of EU cohesion policy in the field of equalizing development opportunities in the peripheral regions from the mid-1980s (Pastuszka, 2012). The system was based on a policy understood as coordination of interests rather than rivalry, which was a revolutionary approach to politics on the European continent. Thanks to these standards, the European system incorporates new peripheral areas into its influence zone through voluntary adaptation and cooperation, not through conquest or coercion. In this sense, the current European centerperiphery model differs from the imperial models practiced by the $19^{\text {th }}$-century powers and by the USSR. 


\section{Summary}

Center-periphery theories underline the asymmetry in the potential of regions and states. In the process of ensuring energy security, CEE countries are characterized by a historically conditioned dependence on Russia which should be understood as so-called "development path dependence". The process of reducing the dependence of this region on the former center has been strengthened by the accession of the majority of CEE countries to the European Union. A voluntary presence in the EU structure results in the modernization of legislation and the infrastructure base, and change in the structure of supply and types of energy. By establishing standards respected by several dozen of its member states and neighbors, the European Union enables the former peripheries of the USSR to increase expenditure to change their model of energy supply into one that is more diversified and ecological. However, the costly energy transformation will take several decades.

The EU-15 countries are still the center of the European economy. The strict center of the continent is the so-called "European Pentagon", meaning a figure with points in London, Paris, Hamburg, Munich and Milan. This area covers about $12 \%$ of the EU, is inhabited by $30 \%$ of the population and generates over $40 \%$ of its GDP (Geographic Diversity of Innovation, 2011). The affluence, security and attractiveness of EU civilization for CEE countries have been unquestionable for several decades and despite the subsequent crises that have plagued the EU after 2008, support for European integration is still high, especially in the CEE region.

Finally, it should be emphasized that the EU has retained in its relations with CEE all the instruments of dominance known from the center-periphery models; however, in a far softer version than was suggested by Wallerstein, Rokkan or Bourdieu. The reason for this is simple: the $\mathrm{EU}$ is not a state; it is a mechanism of inter-state cooperation. The Treaty of Lisbon defines the EU as an international organization with supranational elements whose structure and activity reduces tensions between countries in such a way that none of them dominates the others. In 43 areas defined by treaties, decisions are taken in the EU by a qualified majority, not unanimously. Thus, political dominance within the EU means control, but the member states agree to it voluntarily and can influence its decision-making processes. In accordance with the principle of non-concession, any competence not granted to the EU belongs to its members. The EU operates only within the limits of its competences and cannot independently expand them 
which can be done only through a complicated change to treaties (Aleksandrowicz, 2018, pp. 62-64). Energy competences were therefore established after consultations between member states. The EU has some exclusive competences (referred to in Article 2 Sec. 1 of TFEU and Article 3 Sec. 1 of TFEU), but it shares most of its competences with states (Article 4 Sec. 2 of TFEU), or just supports the states without introducing regulations applicable to each member.

Economic dominance is balanced by support for poorer regions and by access to all anti-poverty instruments. The EU has funds collected from its member states, some of which are net payers (they voluntarily pay more to the EU budget than they receive from it). An imbalance of resources on the continental scale is treated as an opportunity for various developmental specializations but the fuzziest mechanism of domination is in the sphere of culture. The EU-15 countries, due to greater accumulated wealth and previously achieved successes, are able to spend more on culture than CEE countries which had to adjust their legislation and institutions to operate in the conditions of existing integration structures. Most of the treaty provisions as well as ideas, strategies and changes in the EU are derivative of the previous cooperation of Western European countries while in a smaller group and over an extended period of time. From the perspective of peripheral countries, the relative increase in the wealth of their population and the attractiveness of their voluntary presence in the organization means that greater prosperity and manifestations of EU-15 dominance in the current EU structure in various fields are not treated as a threat to CEE security.

With regard to the issue of energy security discussed in this text, the EU has provided CEE countries with economic, financial and political opportunities to increase their energy independence from Russia through the development of energy infrastructure and the co-creation of regulations for the European energy market. However, this did not result in CEE dependence on EU countries, but rather in the diversification of their sources and types of energy. The basic goal of CEE energy security policy (independence from Russia) is becoming achievable. What remains a serious problem is the under-invested energy infrastructure base (considering e.g. the unsatisfactory efficiency and advanced age of most power plant units in Poland) and the limited possibilities of implementing renewable energy sources, which are still too expensive for CEE countries with lower economic resources. In this area, CEE is still a peripheral region since it relies on the support provided by regions richer in capital, technologies and decisionmaking capabilities. The energy issue today and in the future will remain one of the most important indicators of the success of the European project. 


\section{REFERENCES}

Aleksandrowicz, T. R. (2018). Bezpieczeństwo w Unii Europejskiej. Warszawa: Difin.

Babones, S. J., \& Chase-Dunn, Ch. (eds.). Routledge Handbook of World-Systems Analysis. Routledge: London \& New York 2012.

Bourdieu, P. (1986). The Forms of Capital. In J. G. Richardson (ed.), Handbook of Theory and Research for Sociology of Education (pp. 241-258). New York, Westport, CT and London: Greenwood Press.

BP Energy Outlook. (2018). Retrieved from https://www.bp.com/en/global/corporate/ energy-economics/energy-outlook.html

BP Statistical Review of World Energy 2010-2011 (2011). Retrieved from https://www. bp.com/content/dam/bp-country/de_de/PDFs/brochures/statistical_review_of_ world_energy_full_report_2011.pdf

Buzan, B. (1993). People, States and Fear, The National Security Problem in International Relations. Brighton: Wheatsheaf.

Buzan, B., \& Hansen, L. (2009). The Evolution of International Security Studies. New York: Cambridge University Press.

Buzan, B., \& Lawson, G. (2016). The Global Transformation. History, Modernity and the Making of International Relations. Cambridge: Cambridge University Press.

Communication From The Commission To The European Parliament And The Council. European Energy Security Strategy COM/2014/0330 (2014). Retrieved from https:// ec.europa.eu/energy/en/topics/energy-security

Danson, M., \& De Souza, P. (eds.) (2012). Regional Development In Northern Europe. New York: Routledge, Taylor \& Franics.

Delors, J., \& Buzek, J. (2010). Towards A New European Energy Community. Joint Declaration by Jacques Delors and Jerzy Buzek for a New European Energy Community. Retrieved from http://institutdelors.eu/publications/towards-a-new-europeanenergy-community-joint-declaration-by-jerzy-buzek-and-jacques-delors/?lang=en

Departament Ekonomiczny UE, MSZ. (2014). Polskie 10 lat w UE - Raport 2014. Warszawa: Ministerstwo Spraw Zagranicznych.

El-Ojeili, C. (2014). Reflections on Wallerstein: The Modern World-System. Four Decades on. Critical Sociology, 2014, pp. 1-22.

Energy Roadmap 2050: a secure, competitive and low-carbon energy sector is possible. (2011). Retrieved from http://europa.eu/rapid/press-release_IP-11-1543_en.htm

Energy security quest in Central and Eastern Europe. Achievements and challenges. (2016). Central Europe Energy Partners. Retrieved from https://www.ceep.be/3176-2/

EU Energy in Figures. Statistical Pocketbook 2016 (2016). Luxembourg: Publications Office of the European Union.

European Community. (7 Feb 1992) Treaty on European Union. Official Journal of the European Communities C 191 (35), 29 July 1992. Retrieved from https://eur-lex. europa.eu/legal-content/EN/TXT/?uri=celex\%3A11992M\%2FTXT 
European Council \& Council of the European Union (2015). Energy Union for Europe. Retrieved from https://www.consilium.europa.eu/pl/policies/energy-union/

Gapminder Trends. Retrieved from https:/www.gapminder.org/

Geograficzne zróżnicowanie innowacji. (2010). Portal Innowacji. Retrieved from http:// www.pi.gov.pl/parp/chapter_86197.asp?soid=7D29B5DA16CA44E0BF9F74349424 EA88

Golarz, M. (2016). Bezpieczeństwo energetyczne Polski na przykładzie zaopatrzenia w gaz ziemny, ropę naftową i energię elektryczną. Bezpieczeństwo. Teoria i Praktyka, 1, 161-179.

Juncker, J. C. (2014). A new start for Europe. Opening statement in the European Parliament plenary session Strasbourg. Retrieved from http://europa.eu/rapid/pressrelease_SPEECH-14-567_en.htm

Klementewicz, T. (2013). Geopolityka trwałego rozwoju. Ewolucja cywilizacji i państwa w trakcie dziejotwórczych kryzysów. Warszawa: Elipsa.

Kochanowicz, J. (1991). The Polish Economy and the Evolution of Dependency. In D. Chirot (ed.), Origins of Backwardness in Eastern Europe. Economics and Politics from the Middle Ages until the Twentieth Century (pp. 94-119). Berkeley - Los Angeles - Oxford: University of California Press.

Kostecki, J. (2016). Wpływ czynników zewnętrznych i wewnętrznych na bezpieczeństwo ekonomiczne Polski. Kwartalnik Naukowy Uczelni Vistula, 3(49), 53-80.

Krzak, J. (2010). Bezpieczeństwo energetyczne Unii Europejskiej. Biuro Analiz Sejmowych. Retrieved from http://orka.sejm.gov.pl/WydBAS.nsf/0/D1B1C467B378465 FC12578E3004384E2/\$file/Bezpiecze\%C5\%84stwo_energetyczne.pdf

Księżopolski, K. M. (2011). Bezpieczeństwo ekonomiczne. Warszawa: Elipsa.

Laskowicz, T. (2016). Polityczne aspekty dywersyfikacji dostaw gazu i ropy naftowej do Polski, a bezpieczeństwo energetyczne Unii Europejskiej. Securitologia, 2, 119-129.

Molo, B. (2016). Polityka Unii Europejskiej a rozwój odnawialnych źródeł energii w Niemczech. Rocznik Integracji Europejskiej, 10, 121-142.

OECD (2005). OECD Science, Technology and Industry Scoreboard. Paris: OECD.

Olszewski, P. (2010). Bezpieczeństwo energetyczne - quo vadis Europo? Myśl Ekonomiczna i Polityczna, 3(30), 105-126.

Orłowski, W. (2010). W pogoni za straconym czasem. Wzrost gospodarczy w Europie Środkowo-Wschodniej 1950-2030. Warszawa: PWE.

Pastuszka, S. (2012). Polityka regionalna UE: Cele, narzędzia, efekty. Warszawa: Difin.

Paszkiewicz, E. (2018). Bezpieczeństwo energetyczne Unii Europejskiej w sektorze gazu ziemnego. Przegląd Geopolityczny, 23, 123-143.

Pawłuszko, T. (2017), Między zachodem a wschodem. Polska w perspektywie długiego trwania. Miscellanea Oeconomicae, 2, 49-74.

Prebisch, R. (1959). Commercial Policy in the Underdeveloped Countries. American Sociological Review, 49(2), 251-273. 
Rokkan, S. (1980). Territories, Centres, and Peripheries: Toward a Geoethnic-Geoeconomic-Geopolitical Model of Differentiation Within Western Europe. In J. Gottmann (ed.), Centre and Periphery: Spatial Variation in Politics (pp. 37-57). London: Sage.

Rokkan, S., \& Urwin, D. (eds.). (1982). The Politics Of Territorial Identity. Studies In European Regionalism. London-Beverly Hills-New Delhi: Sage Publications.

Rokkan, S., \& Urwin, D. (1983). Economy, Territory, Identity. Politics of West European Peripheries. London: Sage.

Wallerstein, I. (1974). The Rise and Future Demise of the World Capitalist System: Concepts for Comparative Analysis, Comparative Studies in Society and History, 16, 387-415.

Wallerstein, I. (2001). The End of the World as We Know It Social Science for the TwentyFirst Century. Minneapolis: University of Minnesota Press.

Wojciuk, A. (2018). Empires of Knowledge in International Relations. Abingdon - New York: Routledge.

Yergin, D. (2005). Energy Security and Markets. In Goldwyn, G. L., \& Kalicki, J. H. (eds.), Energy and Security: Toward a New Foreign Policy Strategy. Washington: Woodrow Wilson Center Press with Johns Hopkins University Press.

Zarycki, T. (2014). Ideologies of Eastness in Central and Eastern Europe. New York \& Abingdon: Routledge. 